\title{
Durability Testing of Polymer Electrolyte Fuel Cells Under Stationary and Automotive Conditions
}

\author{
P. Gazdzicki, M. Schulze, K. A. Friedrich
}

German Aerospace Center (DLR), Institute of Engineering Thermodynamics, Pfaffenwaldring 38-40, 70569 Stuttgart, Germany

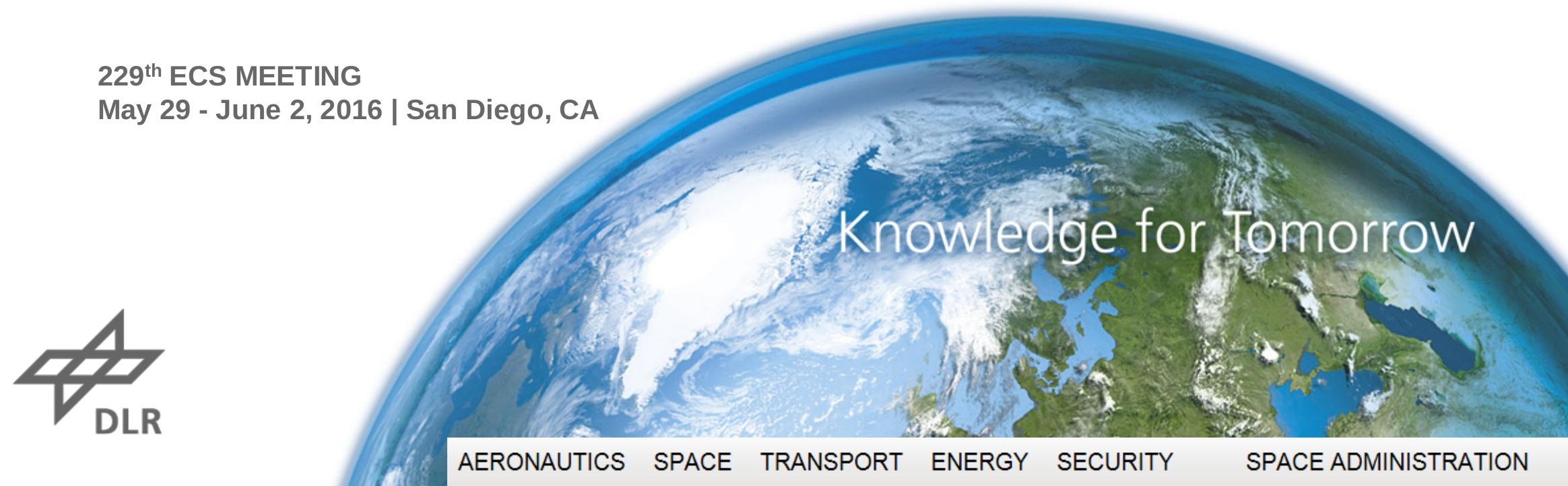


Contents

- Motivation

- Evaluation of irreversible degradation

- Evaluation of reversible degradation

- Recovery of reversible degradation

- Summary 


\section{Motivation}

Performance targets clearly defined and well verifiable, BUT

determination of degradation rates is not well defined.

$\rightarrow$ How to determine if durability goals are achieved?

Discrimination between reversible and irreversible degradation needed

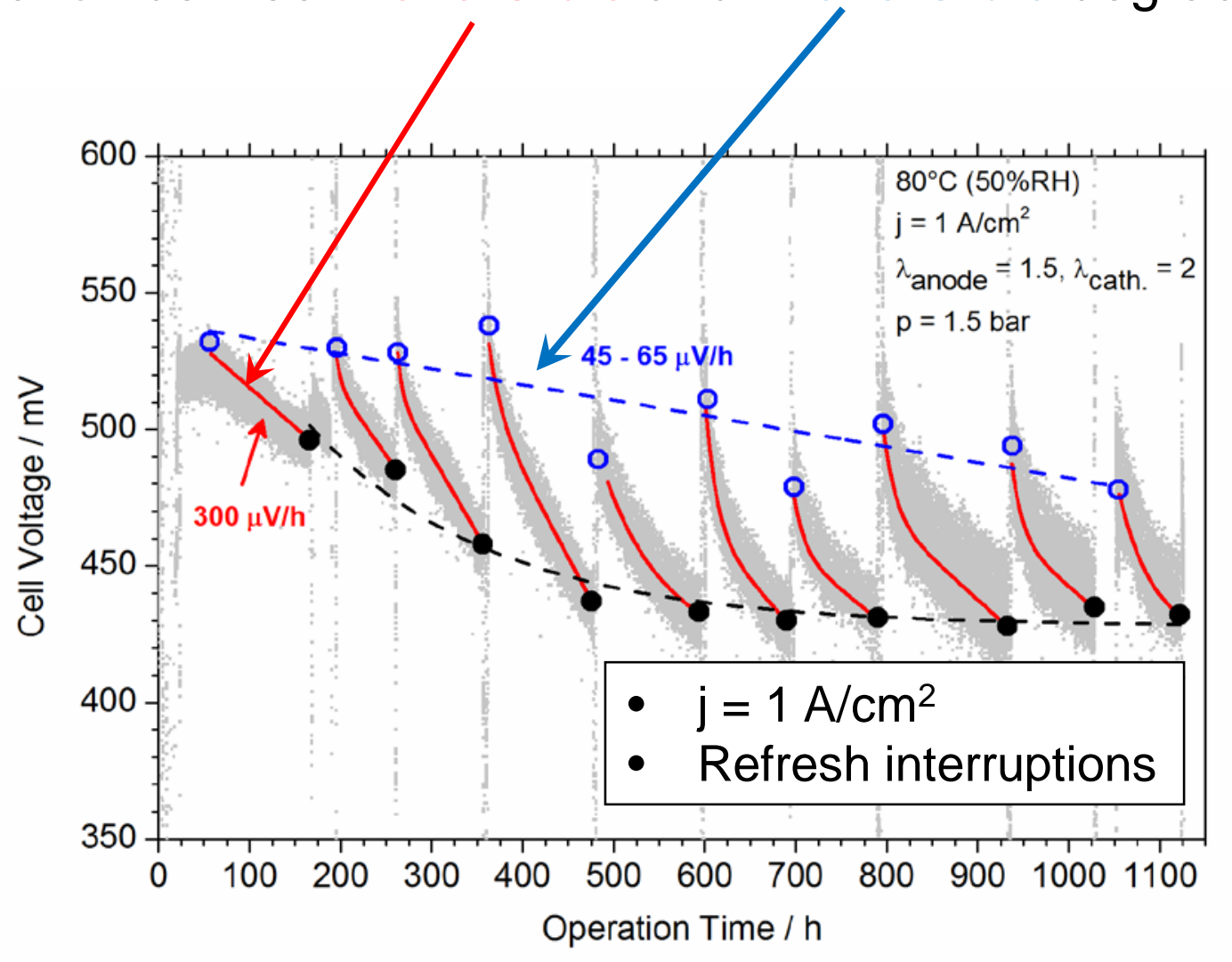




\section{Motivation}

Performance targets clearly defined and well verifiable, BUT

determination of degradation rates is not well defined.

$\rightarrow$ How to determine if durability goals are achieved?

Discrimination between reversible and irreversible degradation needed

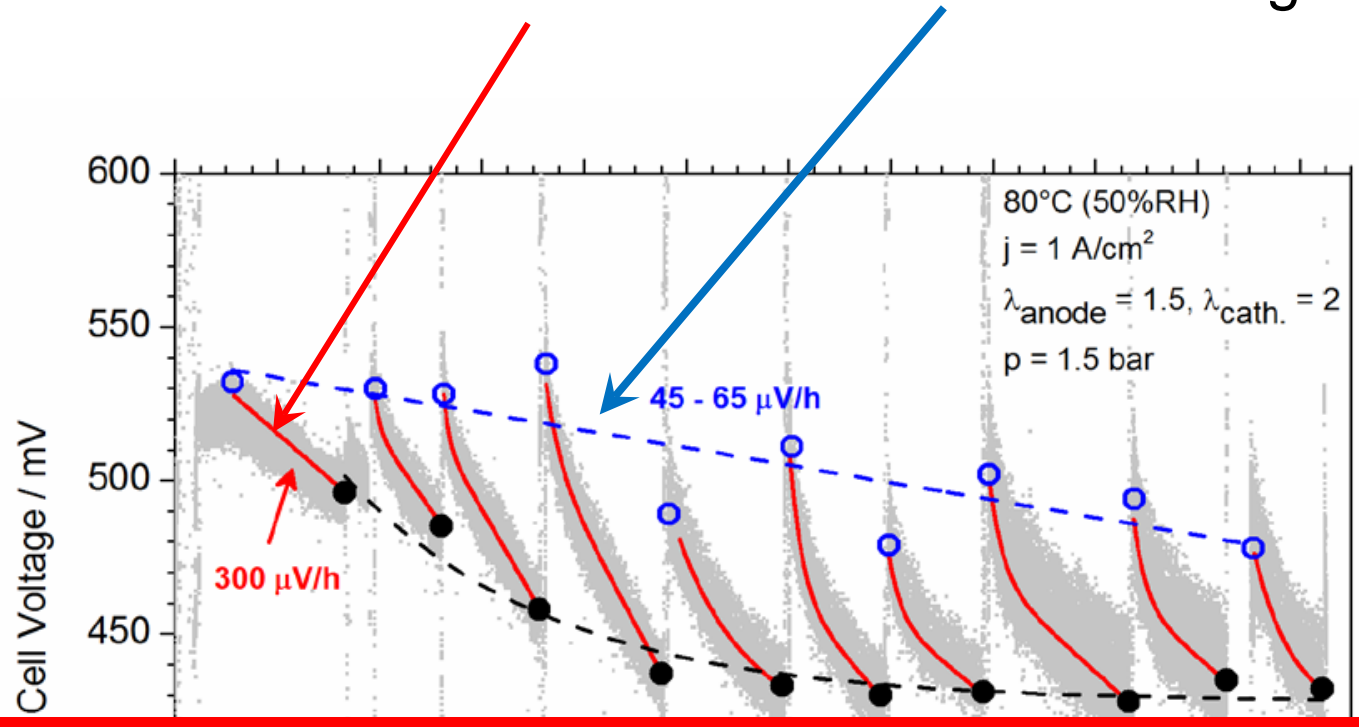

\section{Questions:}

1. How to describe reversible degradation?

2. How to determine irreversible degradation?

3. Does refresh procedure lead to full recovery of reversible losses? 


\section{Evaluation of irreversible degradation}

Durability tests consist of several test blocks of an operation period and a recovery procedure

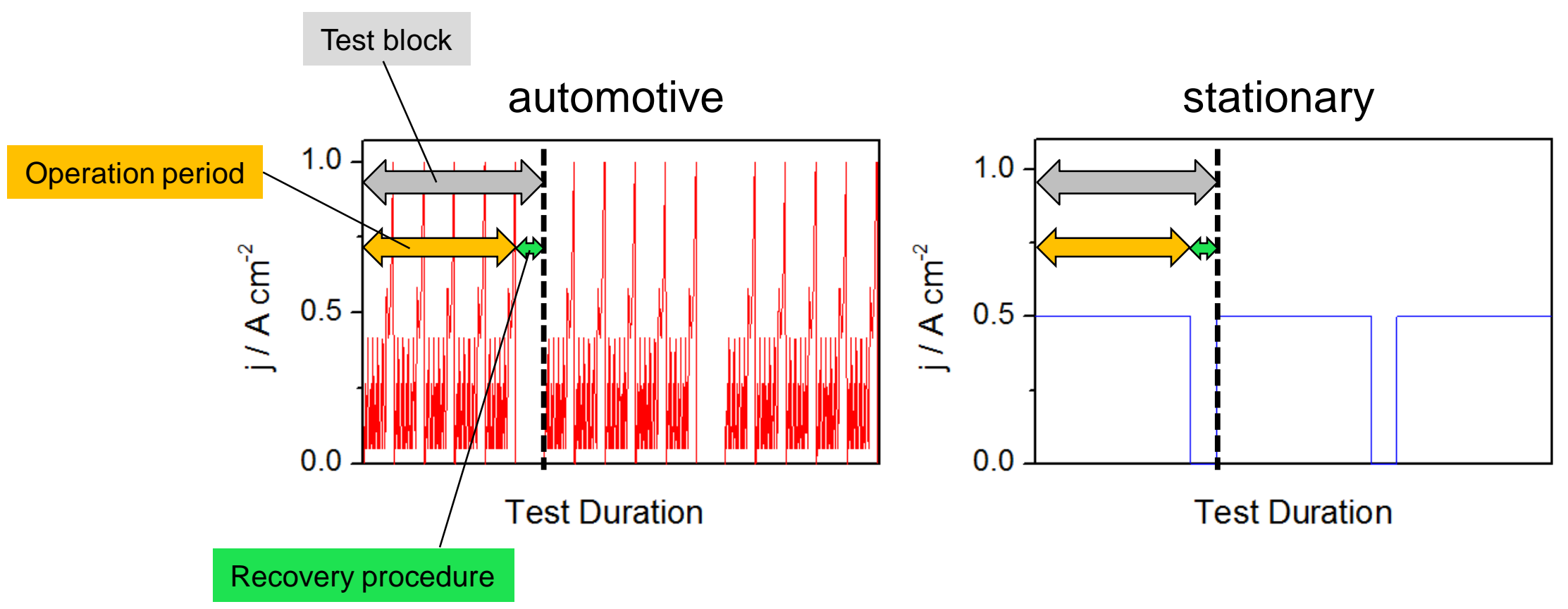




\section{Evaluation of irreversible degradation}

FC dynamic load cycle (FC-DLC) according to FCH-JU StackTest project

$\rightarrow$ Automotive conditions
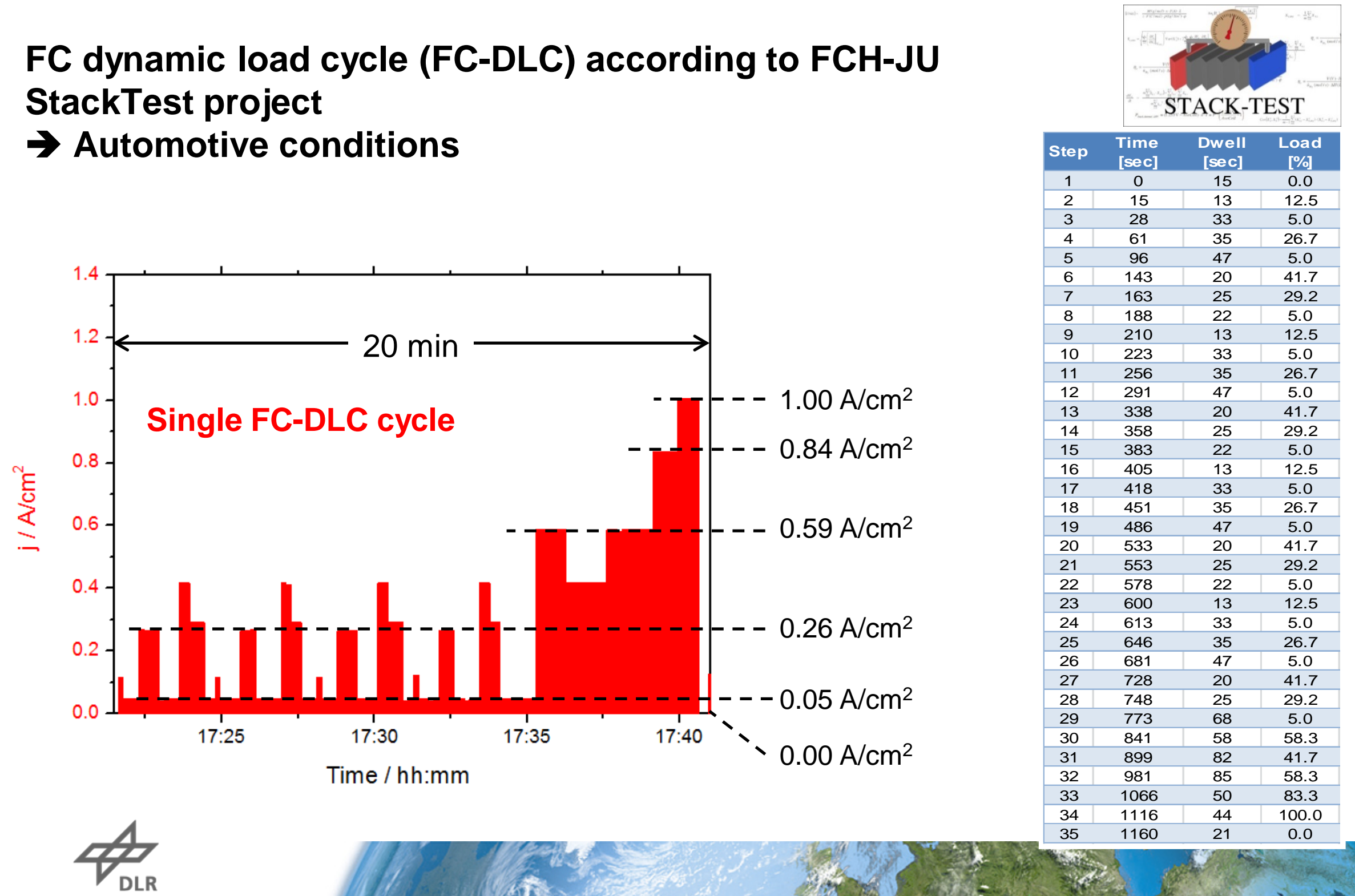


\section{Evaluation of irreversible degradation}

FC dynamic load cycle (FC-DLC) according to FCH-JU StackTest project

$\rightarrow$ Pseudo I-V curve obtained from each cycle

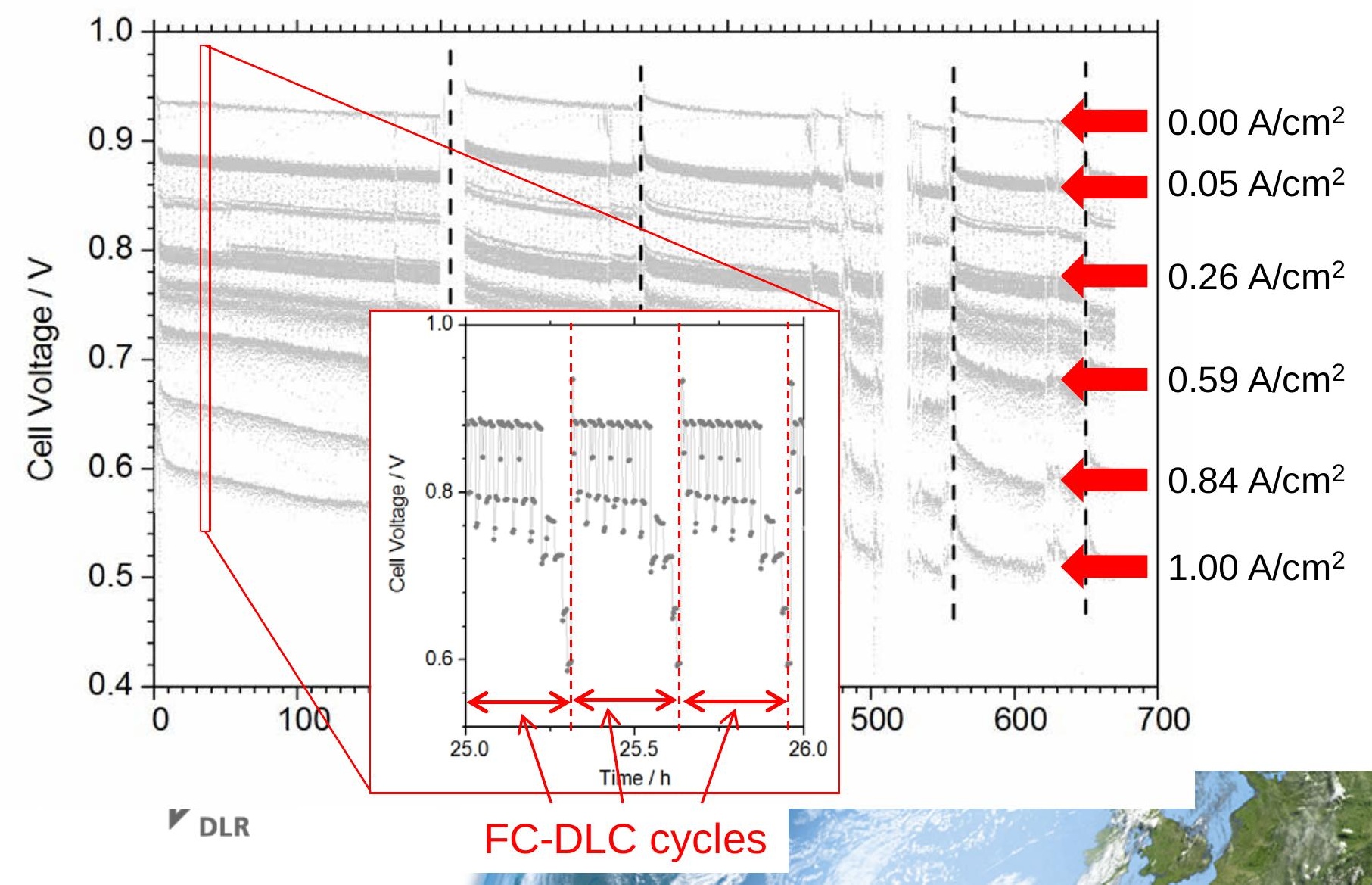




\section{Evaluation of irreversible degradation}

FC dynamic load cycle (FC-DLC) according to FCH-JU StackTest project

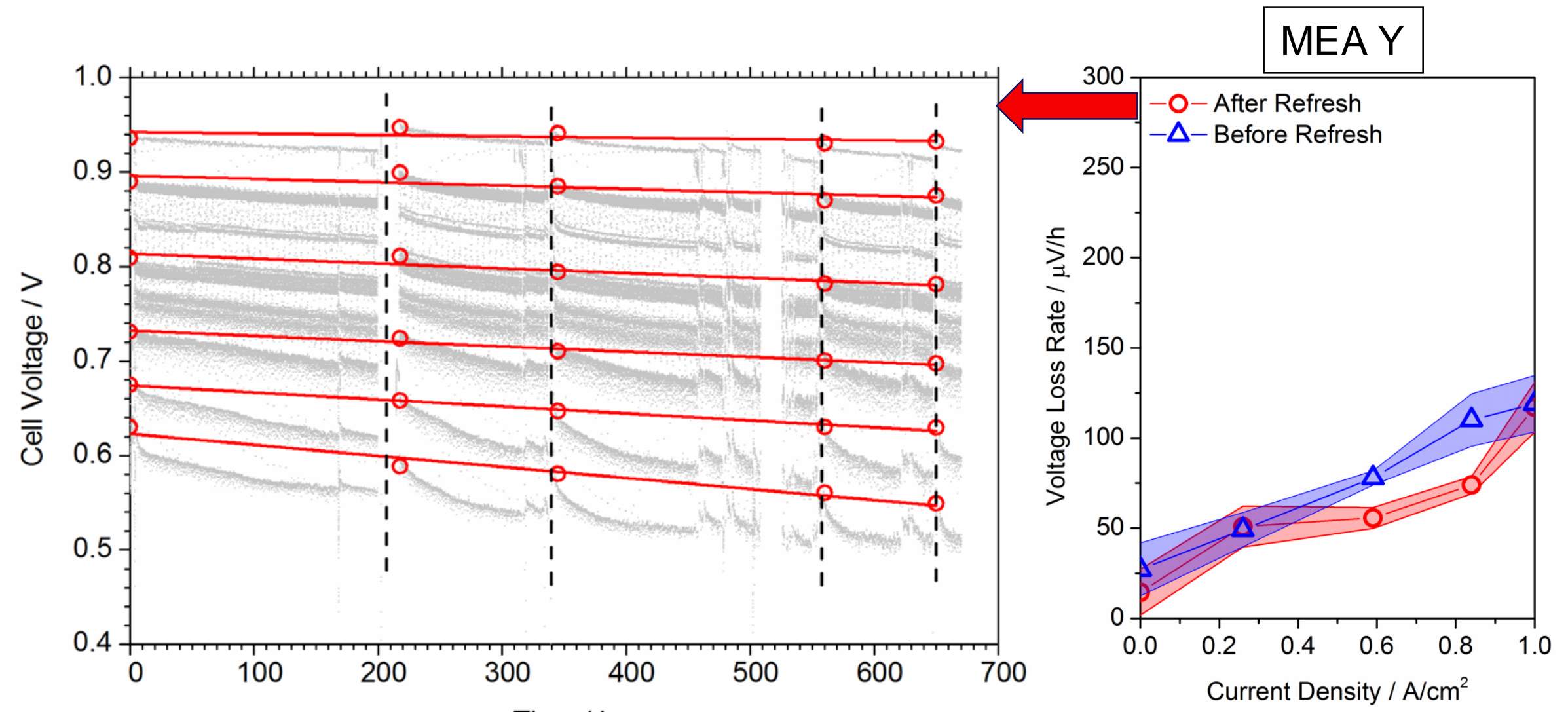




\section{Evaluation of irreversible degradation}

FC dynamic load cycle (FC-DLC) according to FCH-JU StackTest project

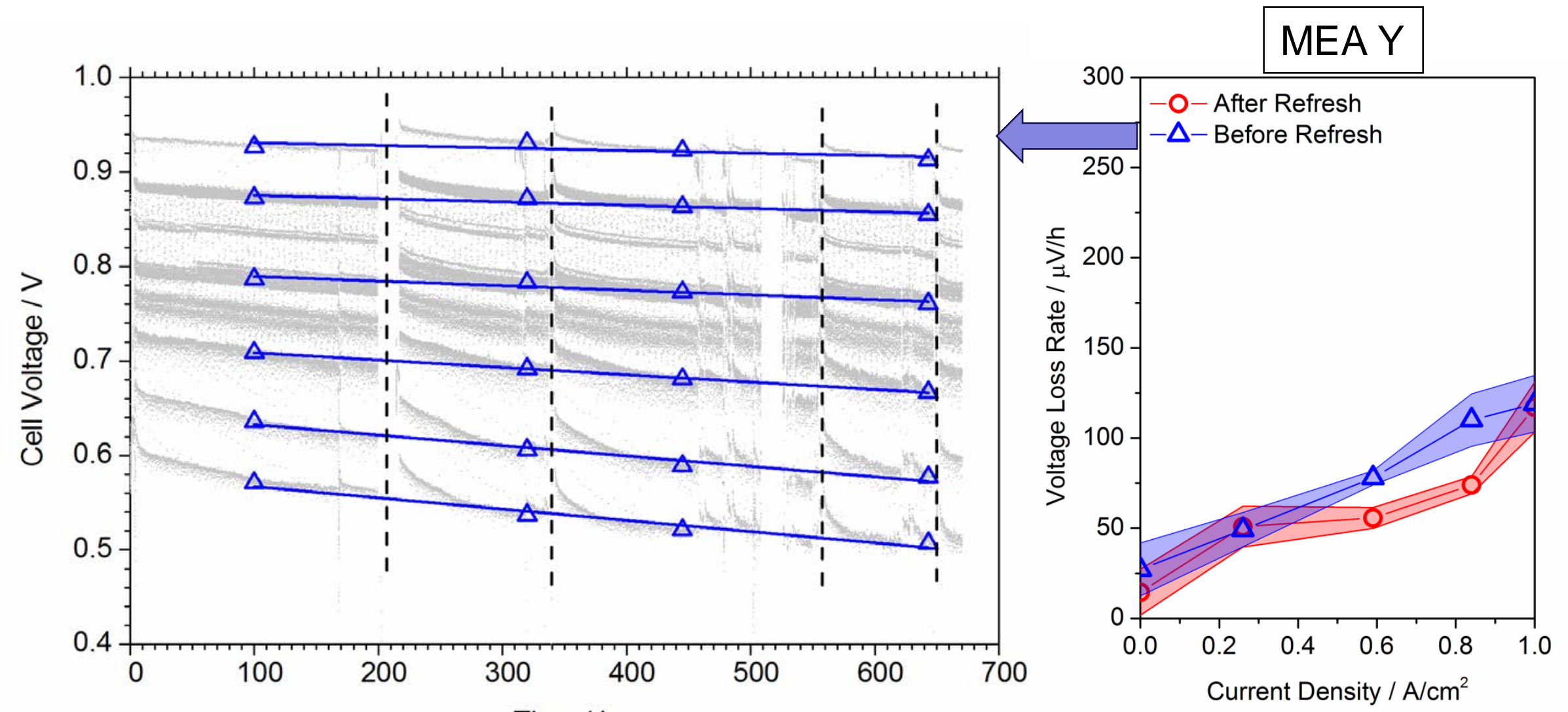




\section{Evaluation of irreversible degradation}

FC dynamic load cycle (FC-DLC) according to FCH-JU StackTest project
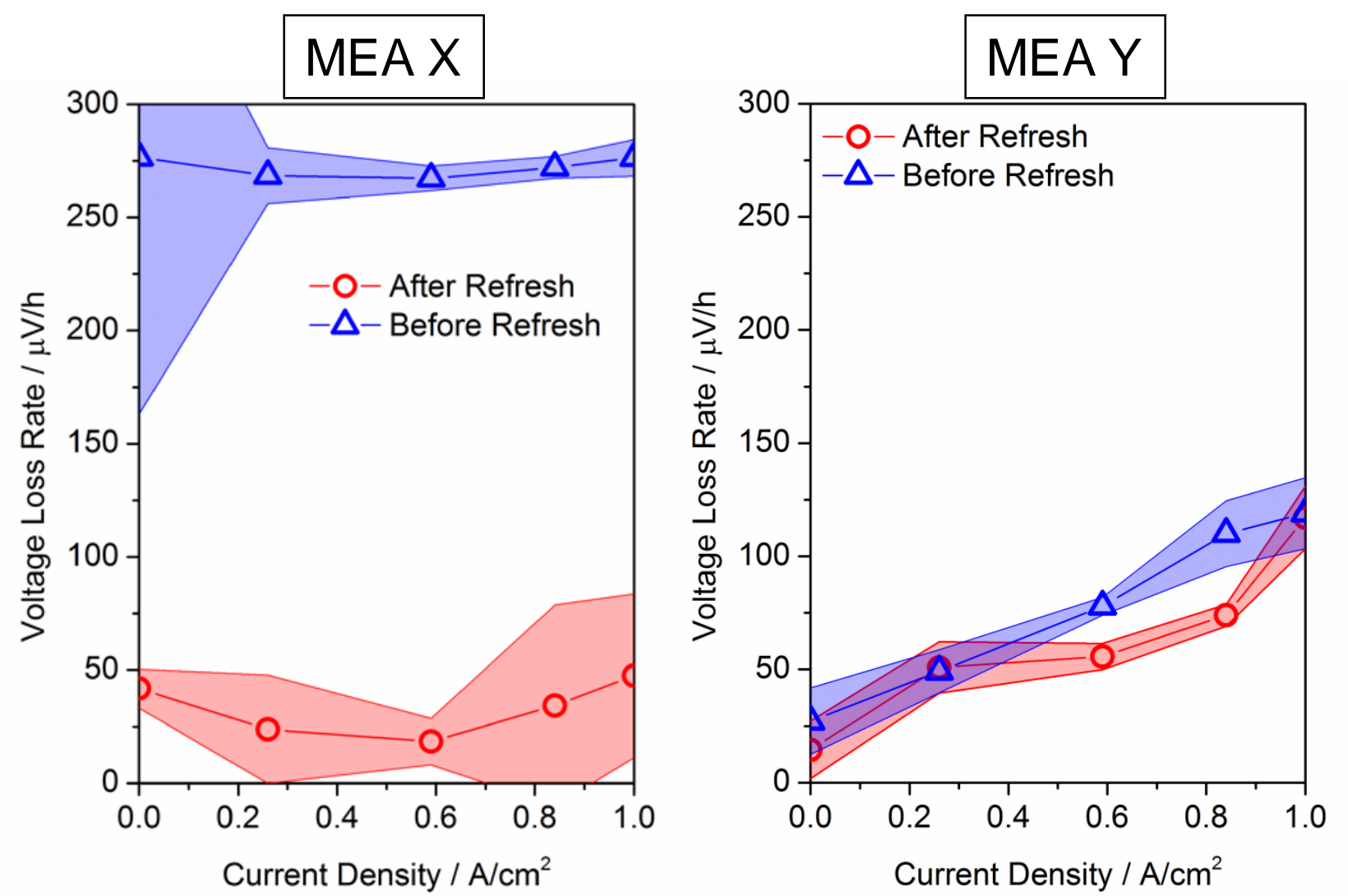

Gazdzicki et al. (2016) J. Power Sources, doi: 10.1016/j.jpowsour.2016.07.049 


\section{Evaluation of irreversible degradation}

\section{Constant and non-constant reversible degradation}

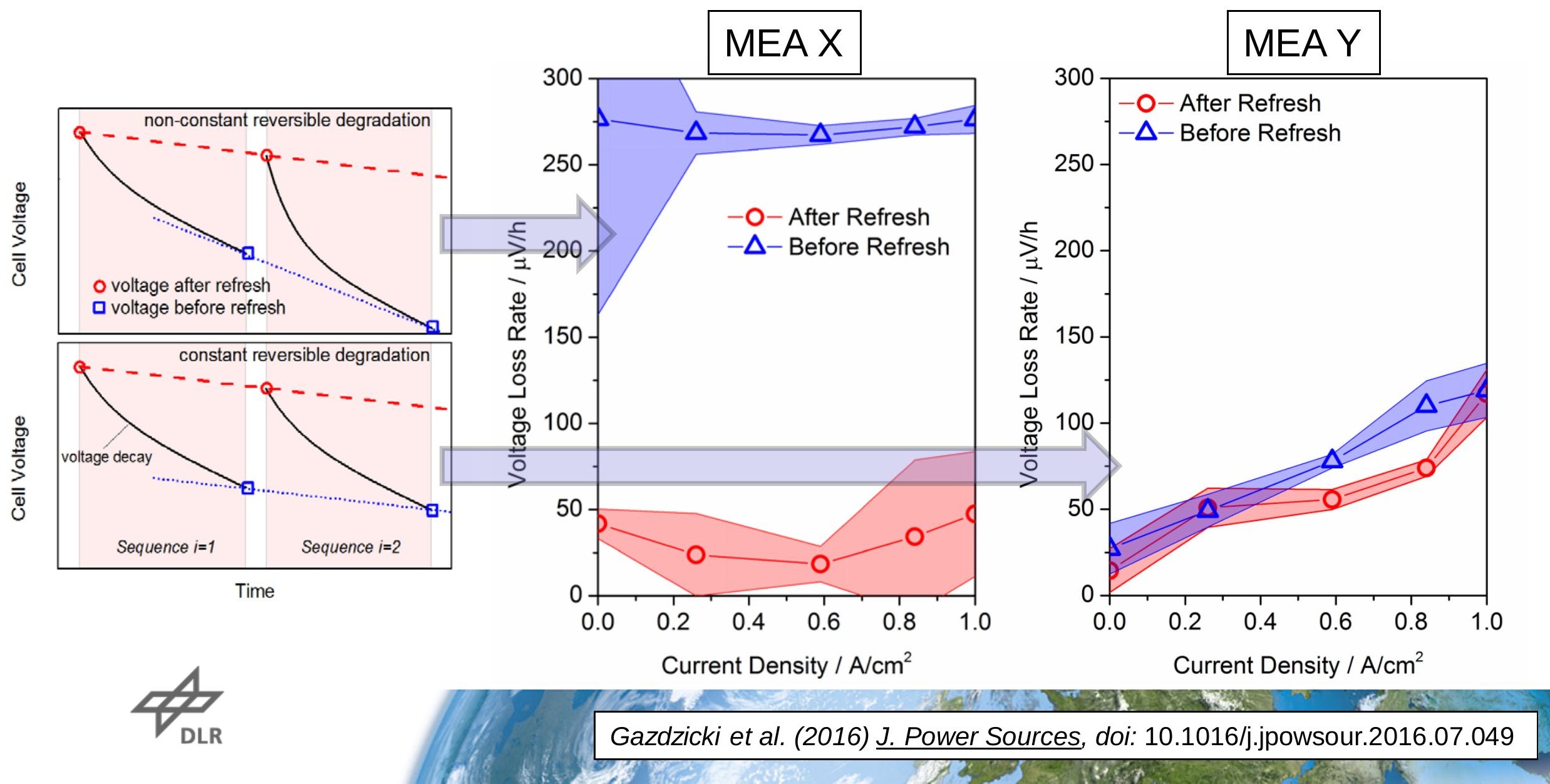




\section{Evaluation of reversible degradation}

Systematic FC dynamic load cycle (FC-DLC) for accurate determination of reversible degradation
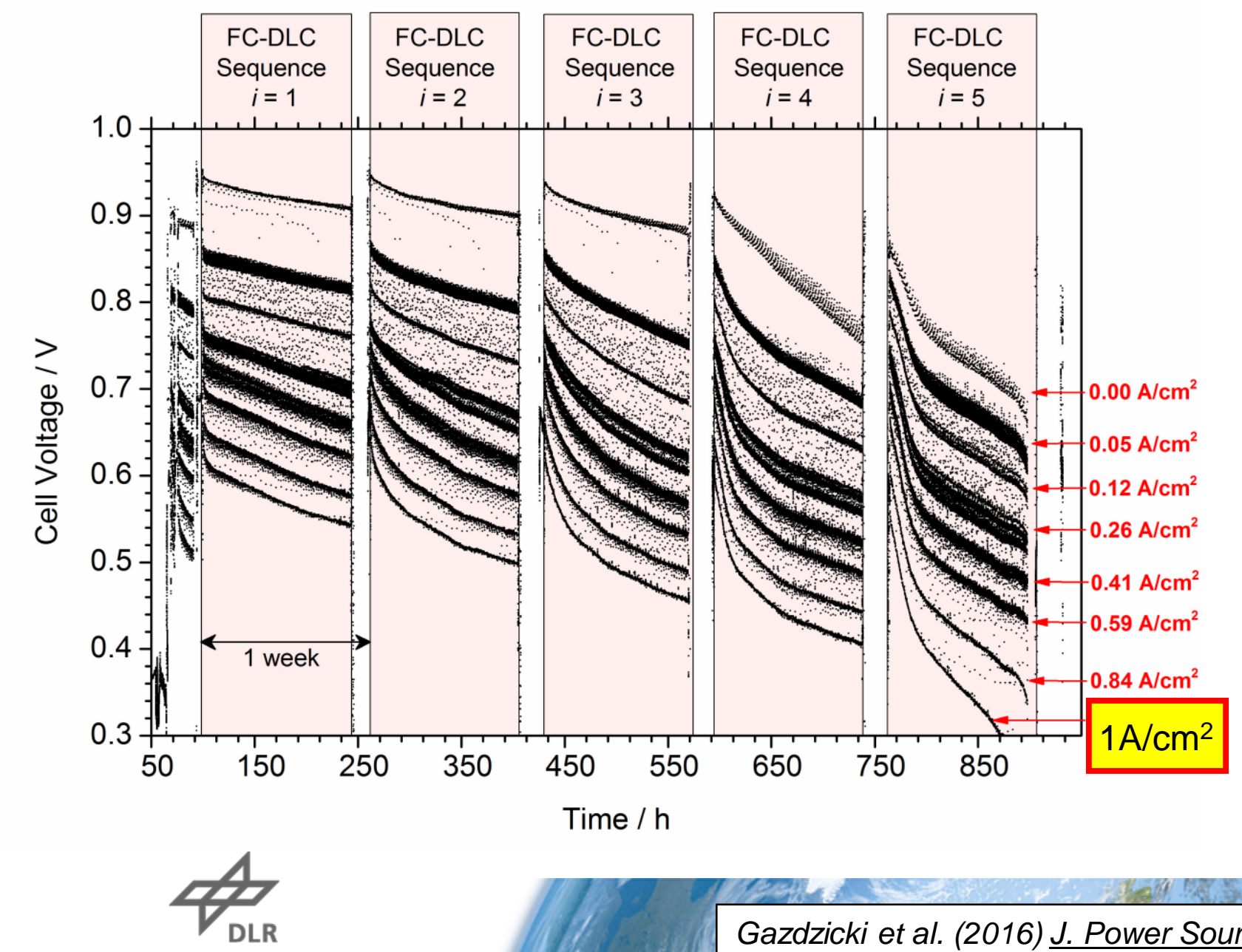


\section{Evaluation of reversible degradation}

\section{Mathematical description of reversible degradation}

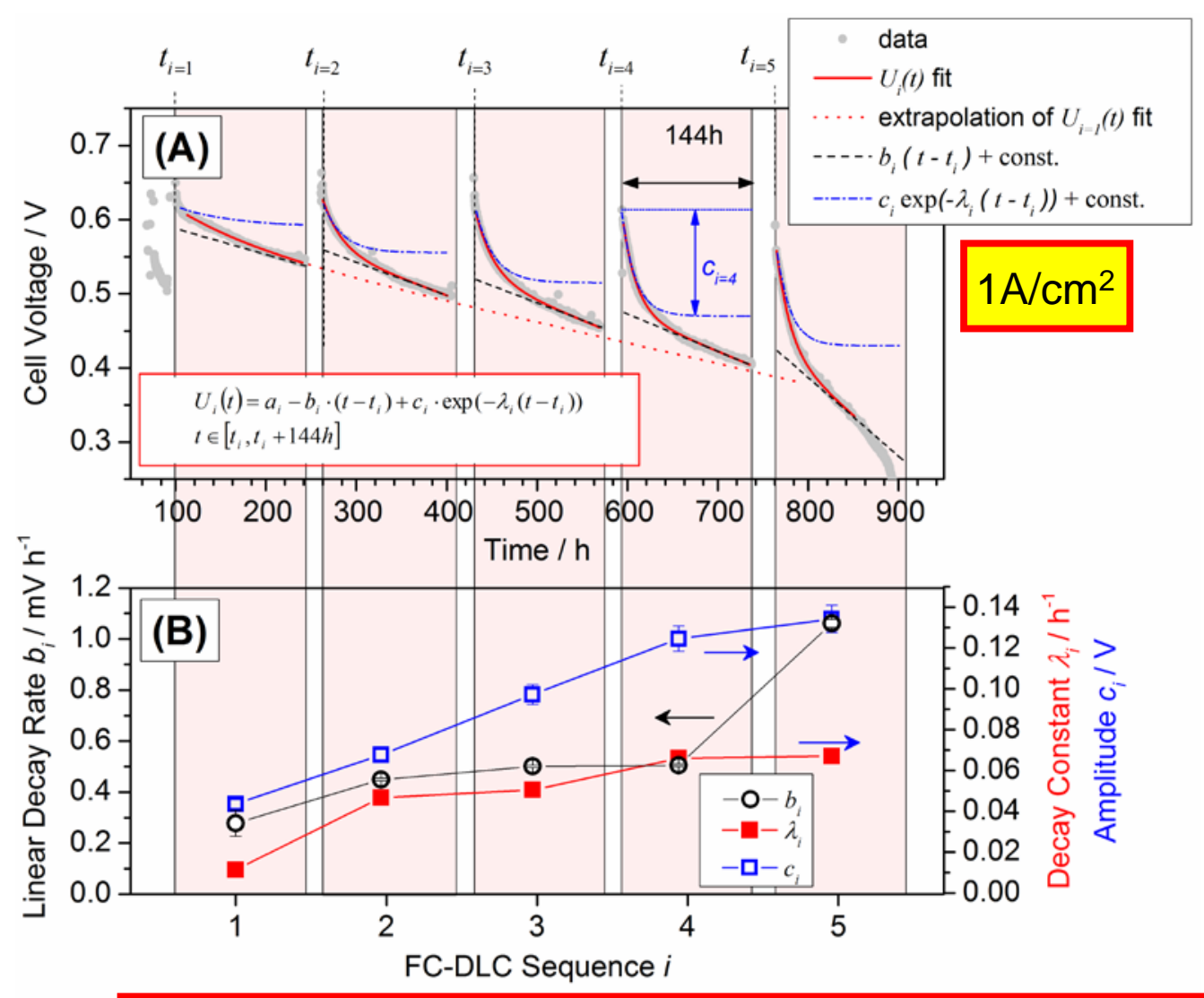

Reversible degradation can be described by a linear-exponential function
Gazdzicki et al. (2016) J. Power Sources, doi: 10.1016/j.jpowsour.2016.07.049 


\section{Evaluation of reversible degradation}

\section{Mathematical description of reversible degradation}

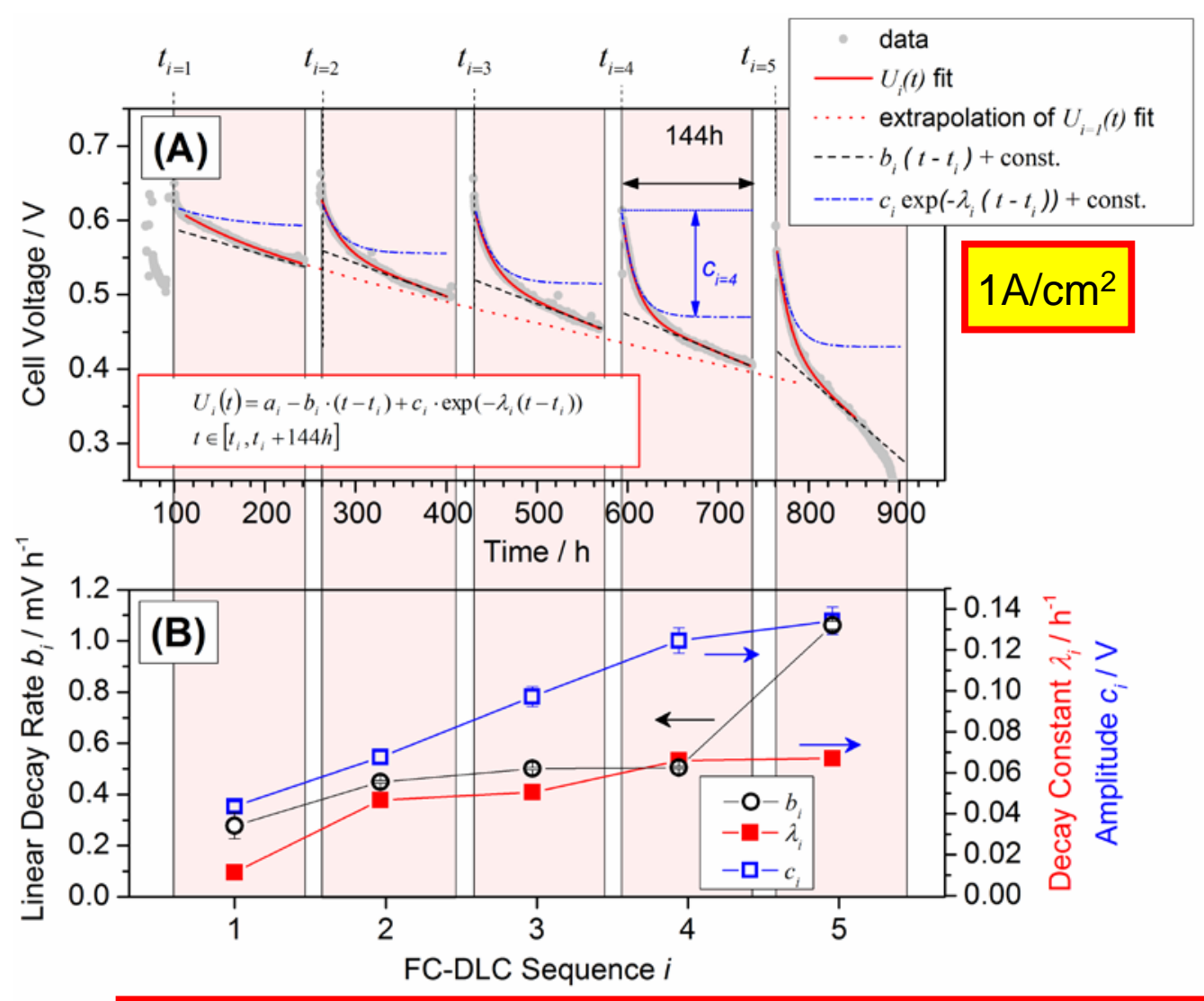

Reversible degradation can be described by a linear-exponential function
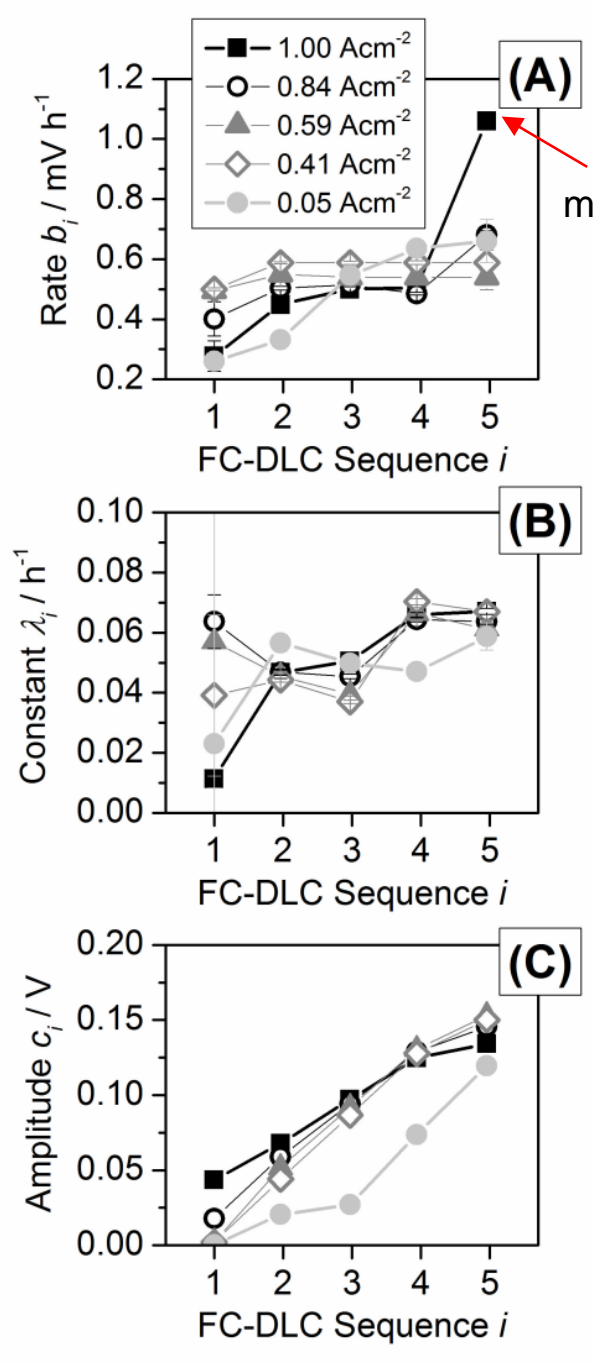


\section{Mathematical description of reversible degradation}

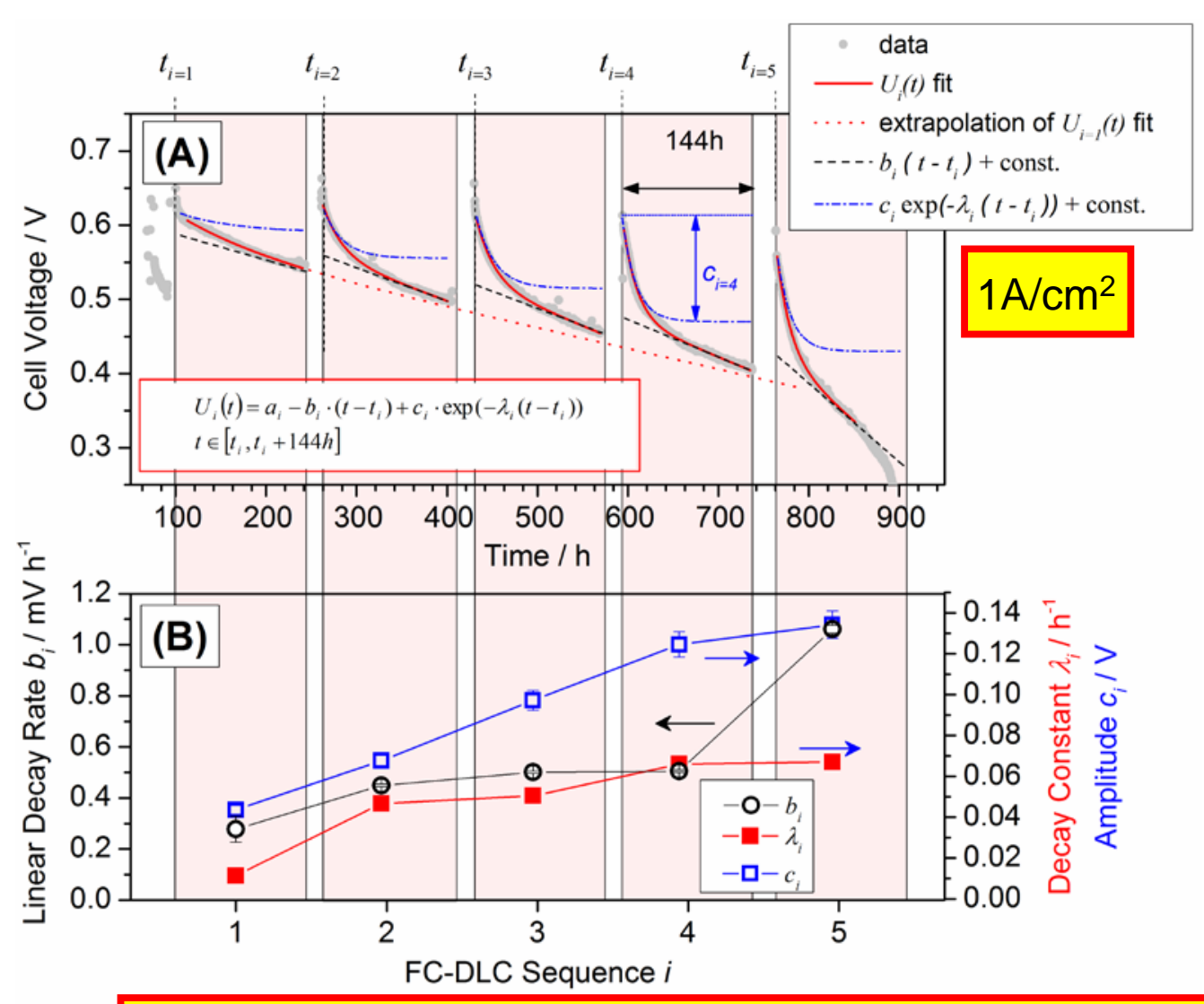

Amplitude of exp. part responsible for increase of reversible degradation with operation time
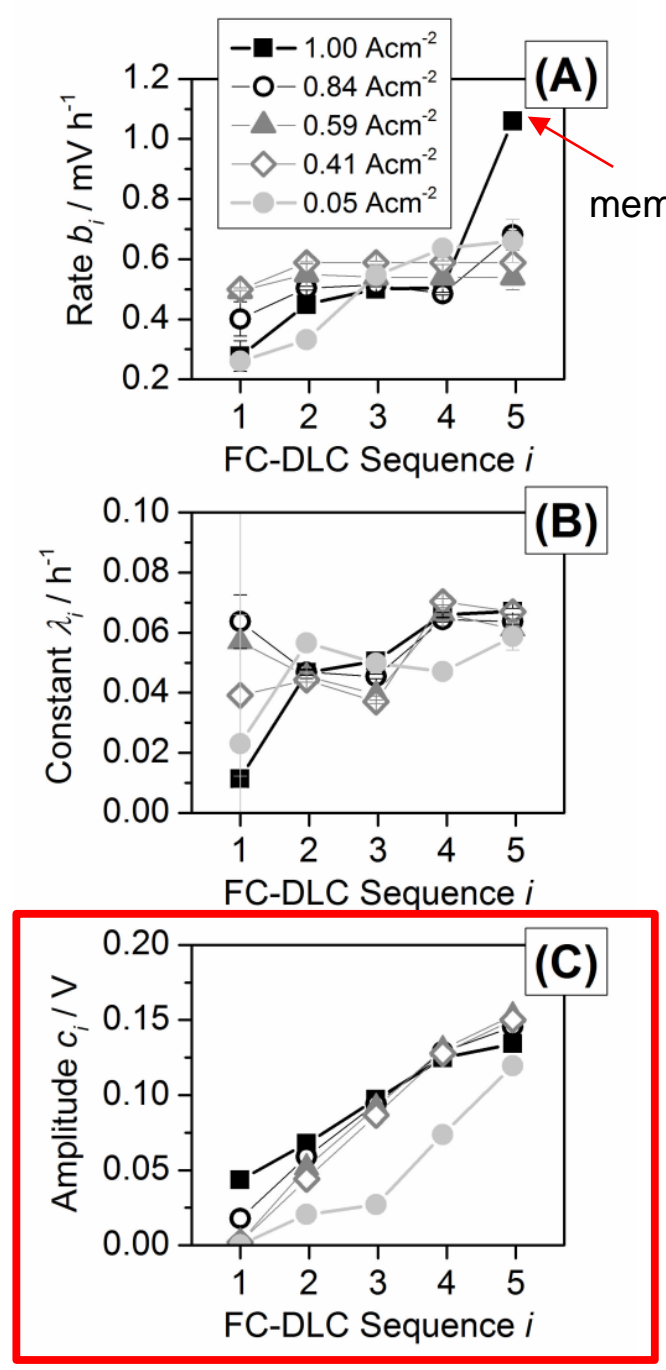


\section{Evaluation of reversible degradation}

\section{Reversible degradation under stationary conditions}
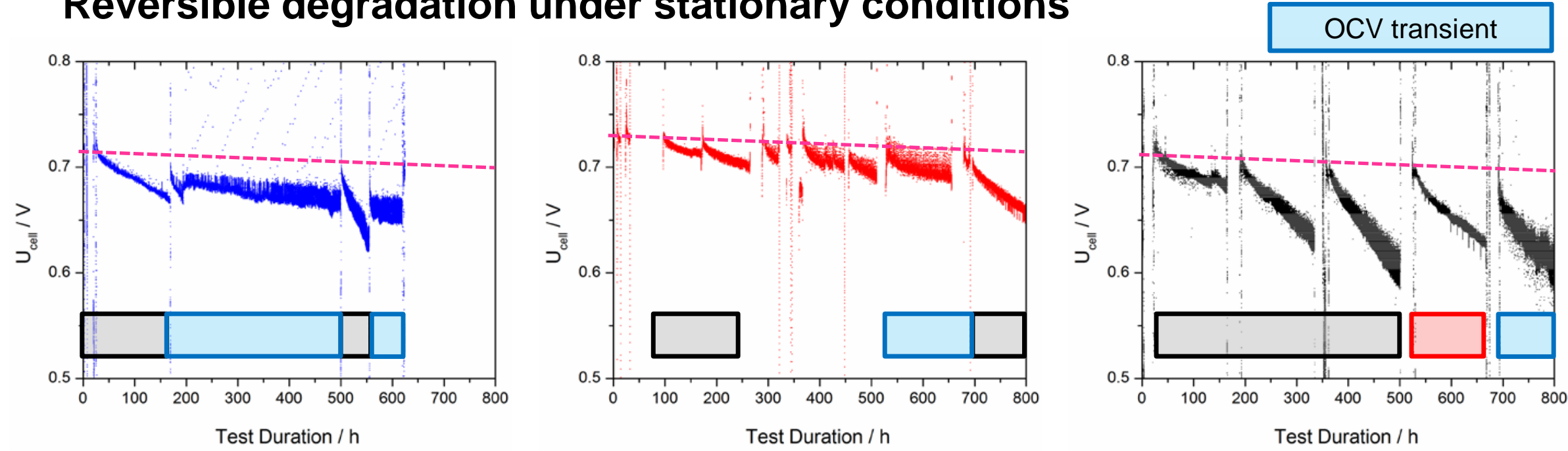

- Irreversibe degradation not sensitive to slight changes of operation conditions

- Reversible degradation depends on operation conditions

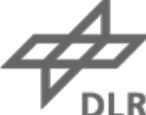




\section{Evaluation of reversible degradation}

\section{Reversible degradation under stationary conditions}
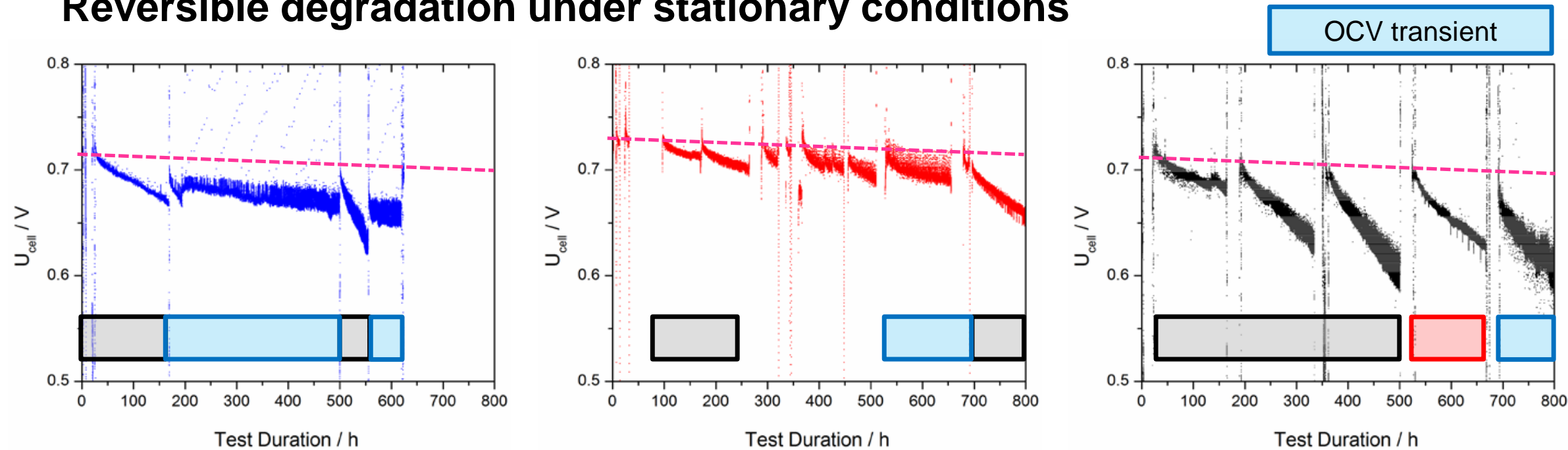

- Irreversibe degradation not sensitive to slight changes of operation conditions

- Reversible degradation depends on operation conditions

Reversible degradation reduced by $\sim 70 \%$ by applying OCV transient

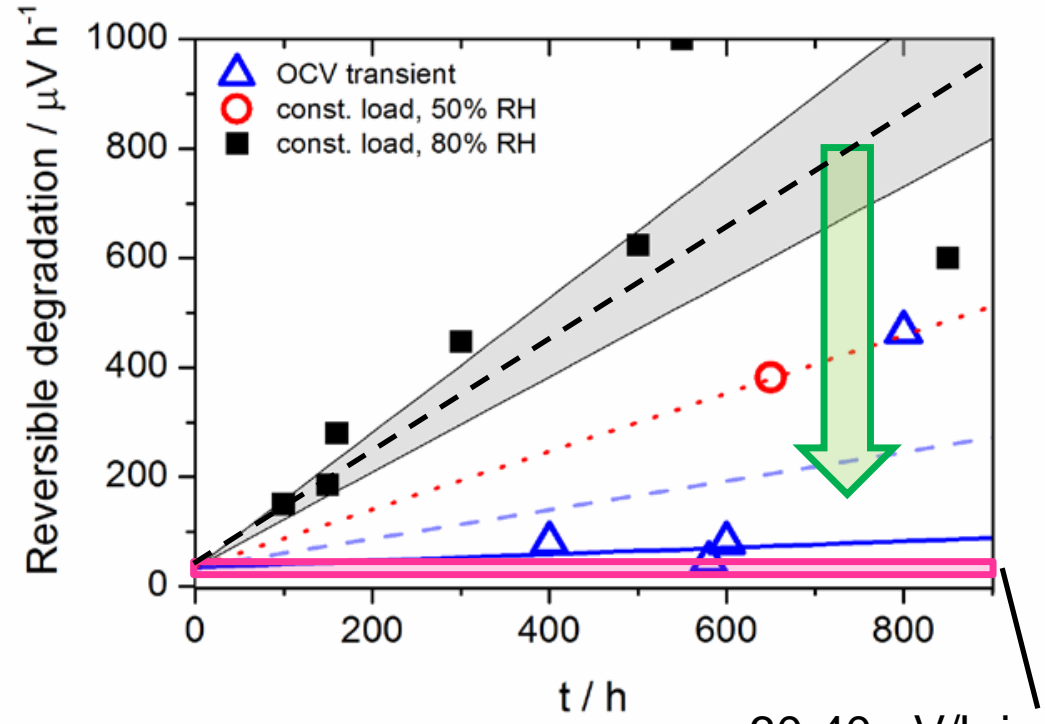

30-40 uV/h irrev. 


\section{Recovery of reversible degradation}

Test of conditions that occur during shutdown recovery procedure and could be the reason for recovery

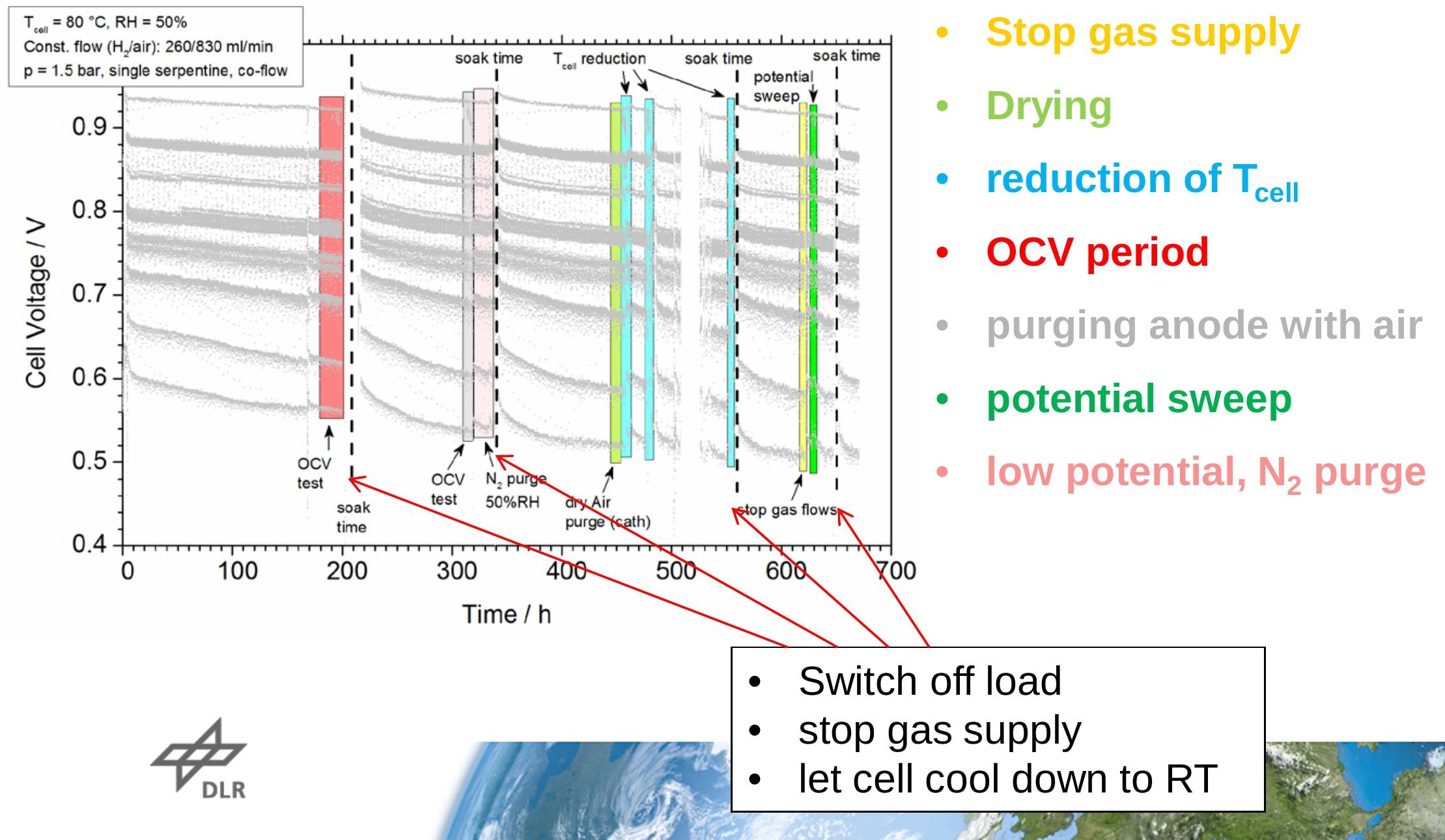




\section{Recovery of reversible degradation}
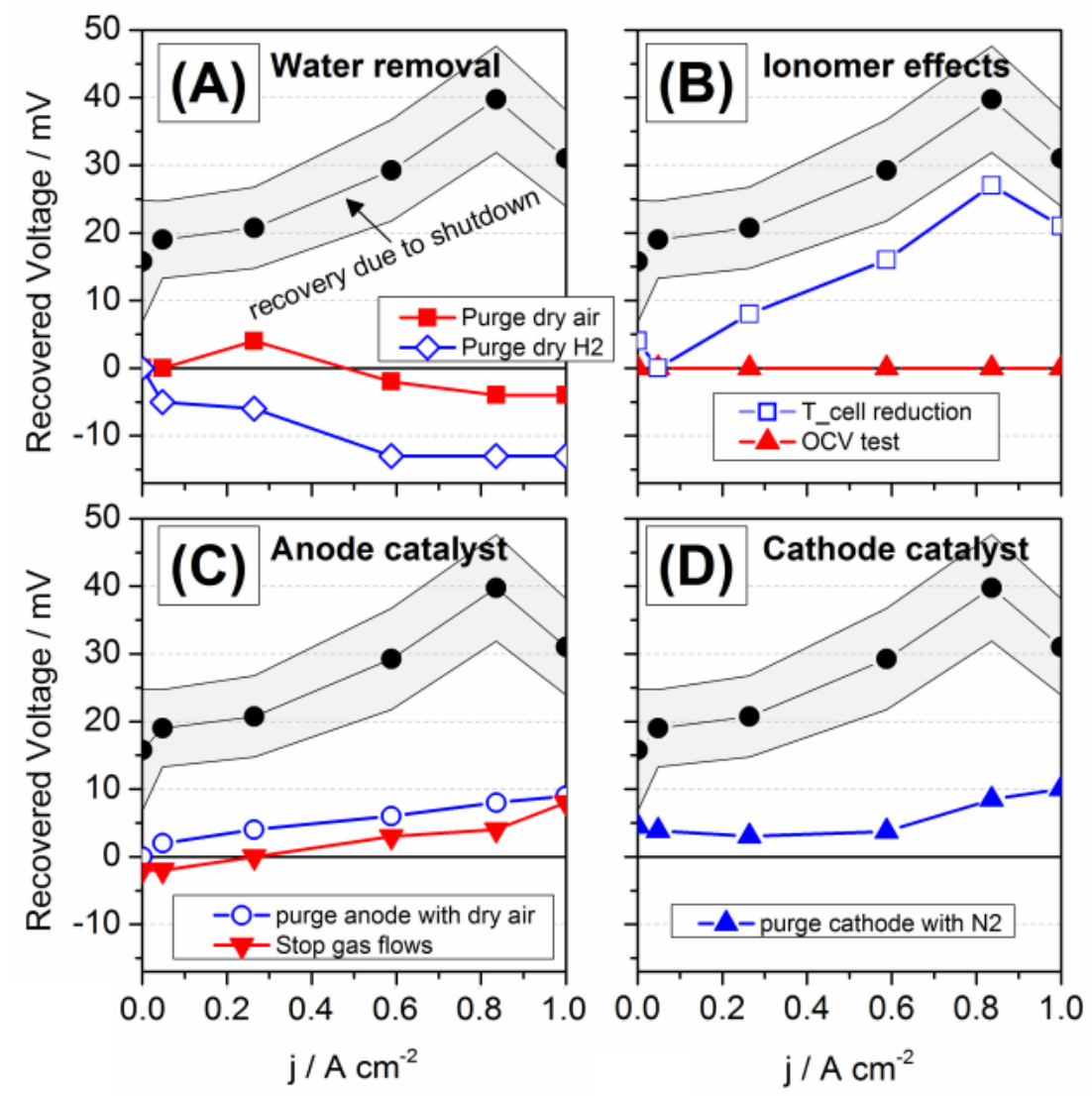

Recovery by shutdown could not be exceeded by any other procedure

$\rightarrow$ It is assumed that shutdown leads to full recovery of reversible losses 


\section{Recovery of reversible degradation}
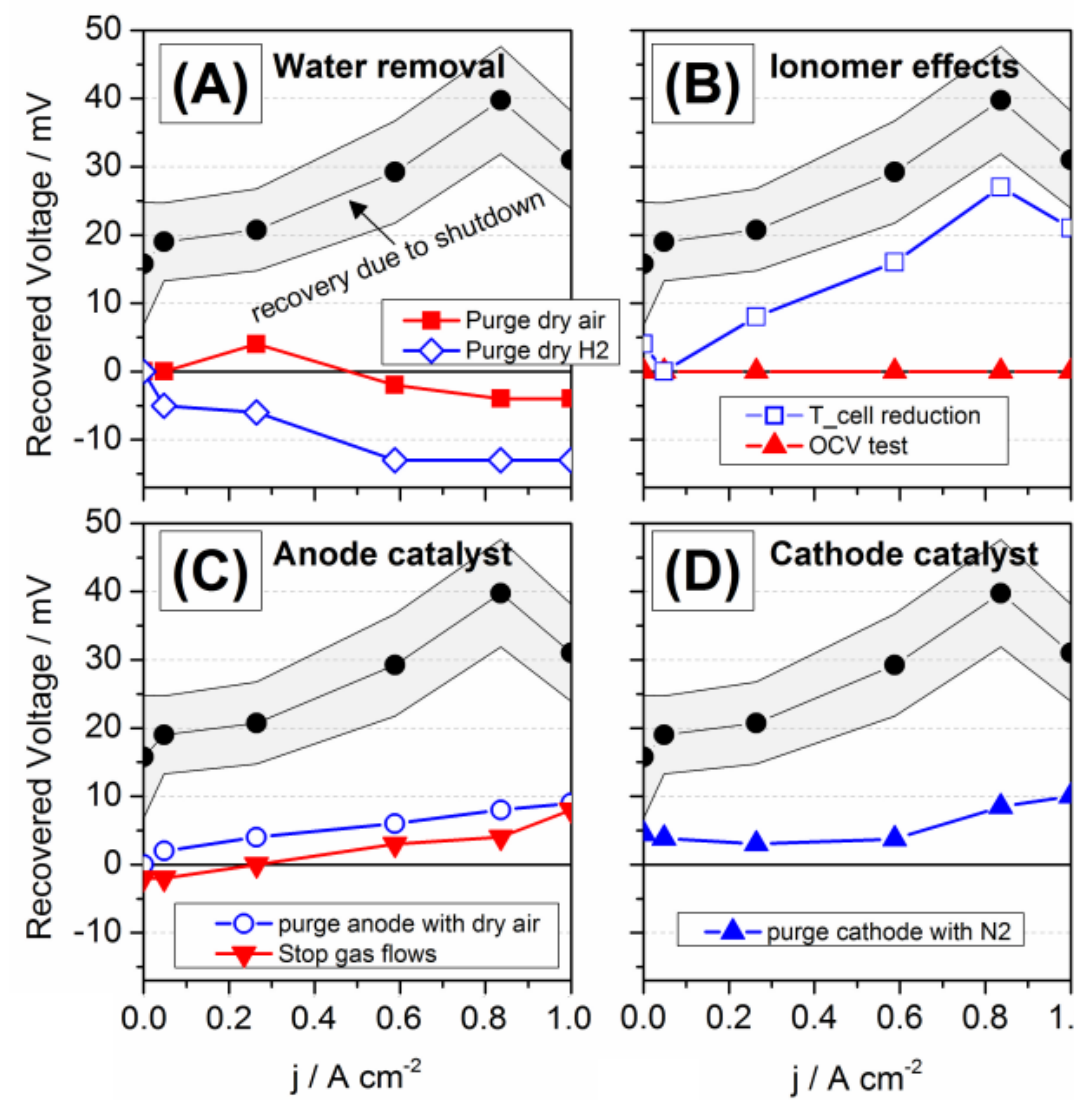

\begin{tabular}{|c|c|c|c|}
\hline Recovery test & Intention & $\begin{array}{l}\text { Recovered } \\
\text { voltage @ } \\
0.2 \mathrm{~A} \mathrm{~cm}^{-2} \\
\end{array}$ & $\begin{array}{l}\text { Recovered } \\
\text { voltage@ } \\
0.8 \mathrm{~A} \mathrm{~cm}^{-2}\end{array}$ \\
\hline $\begin{array}{l}\text { Purging anode } \\
\text { with dry } \mathrm{H}_{2}\end{array}$ & Remove water from anode & $-28 \%$ & $-20 \%$ \\
\hline $\begin{array}{c}\text { Purging } \\
\text { cathode with } \\
\text { dry air }\end{array}$ & Remove water from cathode & $19 \%$ & $-10 \%$ \\
\hline $\begin{array}{l}\text { Reduction of } \\
\text { cell } \\
\text { temperature }\end{array}$ & $\begin{array}{c}\text { Increase humidity and } \\
\text { decrease mechanical } \\
\text { membrane stress }\end{array}$ & $38 \%$ & $68 \%$ \\
\hline OCV-Test & $\begin{array}{c}\text { Drying of MEA and increase } \\
\text { of cathode potential }\end{array}$ & $0 \%$ & $0 \%$ \\
\hline $\begin{array}{l}\text { Purging anode } \\
\text { with air }\end{array}$ & $\begin{array}{l}\text { Increase anode potential to } \\
\text { remove contaminants }\end{array}$ & $19 \%$ & $20 \%$ \\
\hline $\begin{array}{l}\text { Stopping gas } \\
\text { flow }\end{array}$ & $\begin{array}{l}\text { Increase anode potential to } \\
\text { remove contaminants }\end{array}$ & $0 \%$ & $10 \%$ \\
\hline $\begin{array}{l}\text { Purging } \\
\text { cathode with } \mathrm{N}_{2}\end{array}$ & $\begin{array}{l}\text { Decrease cathode potential } \\
\text { to reduce platinum oxide }\end{array}$ & $14 \%$ & $21 \%$ \\
\hline
\end{tabular}

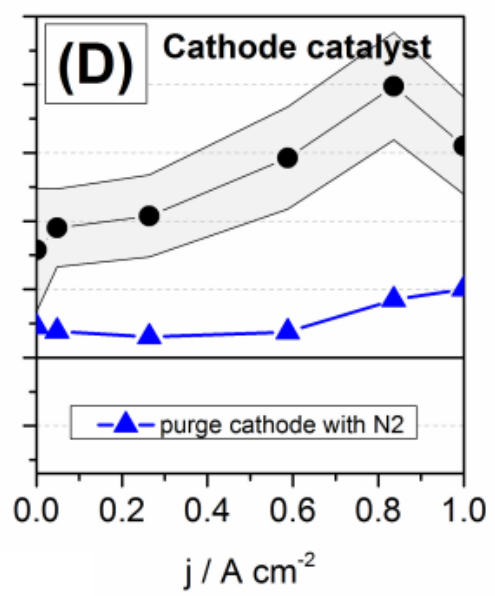

Recovery by shutdown could not be exceeded by any other procedure

$\rightarrow$ It is assumed that shutdown leads to full recovery of reversible losses 


\section{Recovery of reversible degradation}
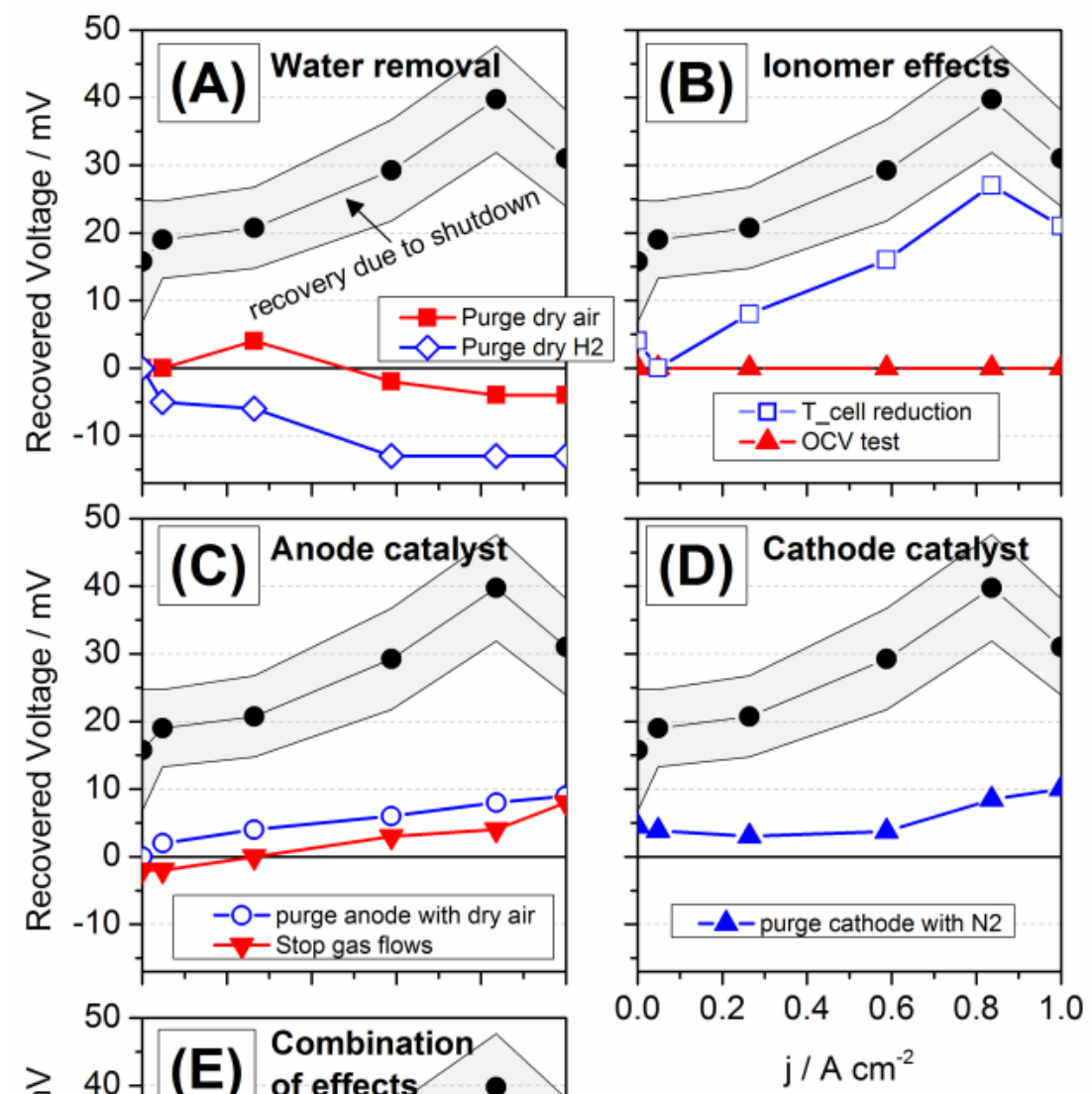

\begin{tabular}{|c|c|c|c|}
\hline Recovery test & Intention & $\begin{array}{l}\text { Recovered } \\
\text { voltage @ } \\
0.2 \mathrm{~A} \mathrm{~cm}^{-2}\end{array}$ & $\begin{array}{l}\text { Recovered } \\
\text { voltage @ } \\
0.8 \mathrm{~A} \mathrm{~cm}^{-2}\end{array}$ \\
\hline $\begin{array}{l}\text { Purging anode } \\
\text { with dry } \mathrm{H}_{2}\end{array}$ & Remove water from anode & $-28 \%$ & $-20 \%$ \\
\hline $\begin{array}{c}\text { Purging } \\
\text { cathode with } \\
\text { dry air }\end{array}$ & Remove water from cathode & $19 \%$ & $-10 \%$ \\
\hline $\begin{array}{l}\text { Reduction of } \\
\text { cell } \\
\text { temperature }\end{array}$ & $\begin{array}{c}\text { Increase humidity and } \\
\text { decrease mechanical } \\
\text { membrane stress }\end{array}$ & $38 \%$ & $68 \%$ \\
\hline OCV-Test & $\begin{array}{c}\text { Drying of MEA and increase } \\
\text { of cathode potential }\end{array}$ & $0 \%$ & $0 \%$ \\
\hline $\begin{array}{l}\text { Purging anode } \\
\text { with air }\end{array}$ & $\begin{array}{l}\text { Increase anode potential to } \\
\text { remove contaminants }\end{array}$ & $19 \%$ & $20 \%$ \\
\hline $\begin{array}{l}\text { Stopping gas } \\
\text { flow }\end{array}$ & $\begin{array}{l}\text { Increase anode potential to } \\
\text { remove contaminants }\end{array}$ & $0 \%$ & $10 \%$ \\
\hline $\begin{array}{c}\text { Purging } \\
\text { cathode with } \mathrm{N}_{2}\end{array}$ & $\begin{array}{l}\text { Decrease cathode potential } \\
\text { to reduce platinum oxide }\end{array}$ & $14 \%$ & $21 \%$ \\
\hline
\end{tabular}

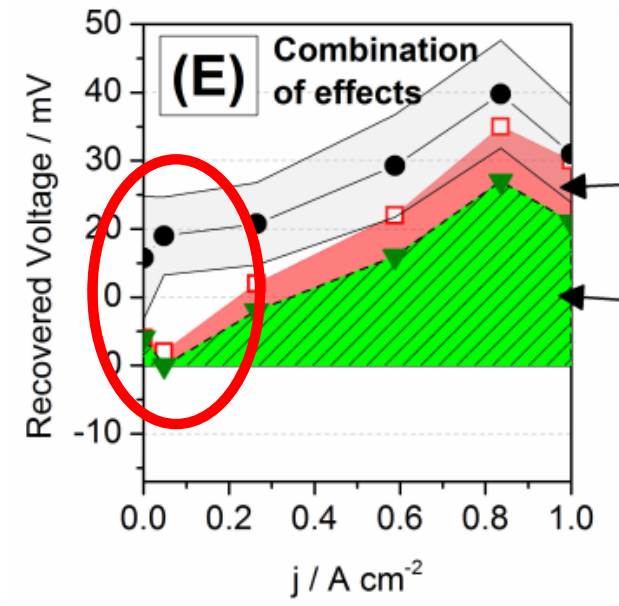

purge anode with air

$T_{\text {cell }}$ reduction

- Water management plays major role in recovery

- Reason for recovery at low loads unclear 


\section{Conclusions}

o Irreversible degradation rate corresponds to linear regression of voltage values after refresh

o Propose to use voltage loss diagrams instead of single value if possible

o Reversible degradation can be described by linearexponential function

o parameter $\mathrm{c}_{\mathrm{i}}$ responsible for acceleration of reversible degradation with time

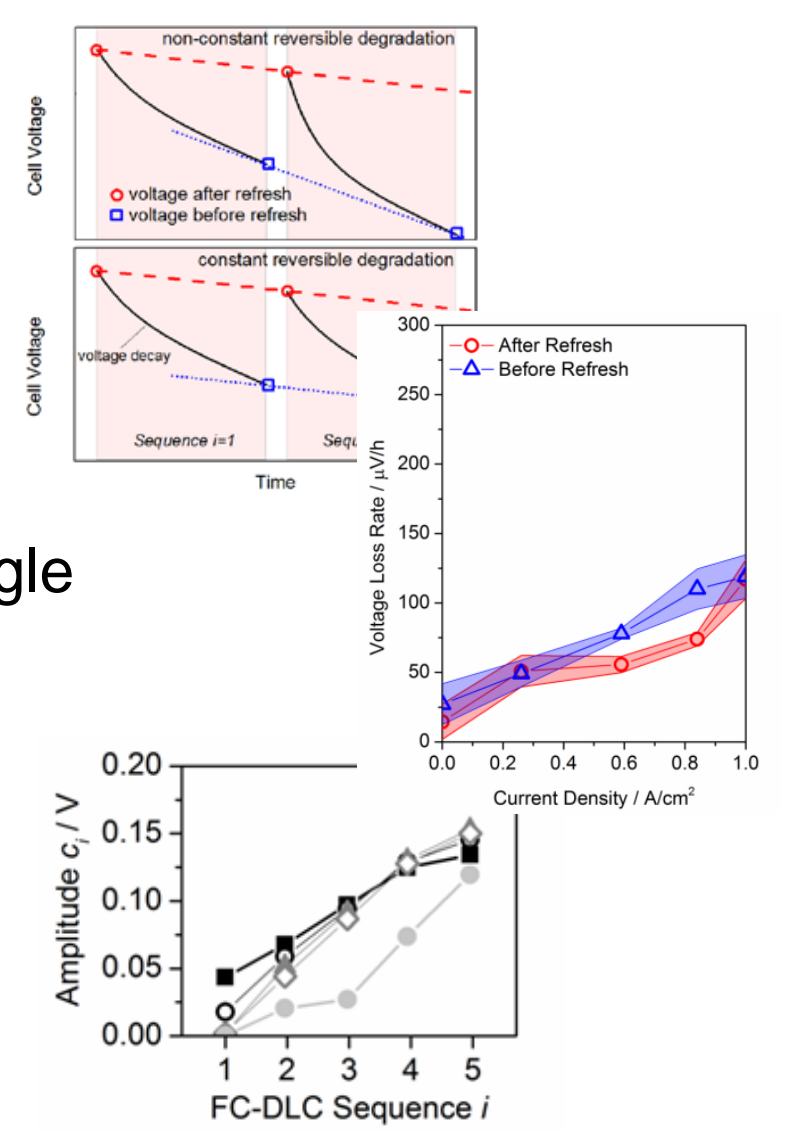

o Reason for voltage recovery:

- Water management plays a role in voltage recovery, especially at high loads

- Recovery at low load not yet explained

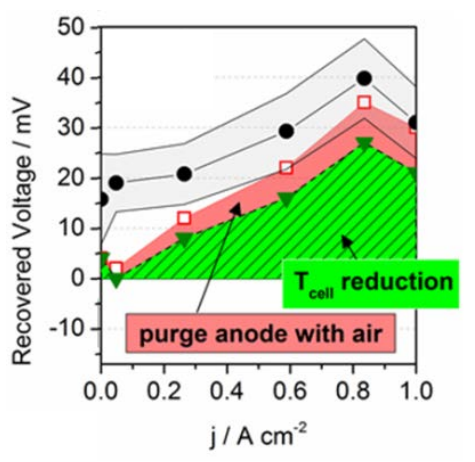




\section{Acknowledgements}

\section{Thank you for your attention.}

The research leading to these results has received funding from the European Union's Seventh Framework Programme (FP7/2007-2013) for Fuel Cell and Hydrogen Joint Technology Initiative under Grant No. 621216 (SecondAct) and Grant n 303452 (Impact).
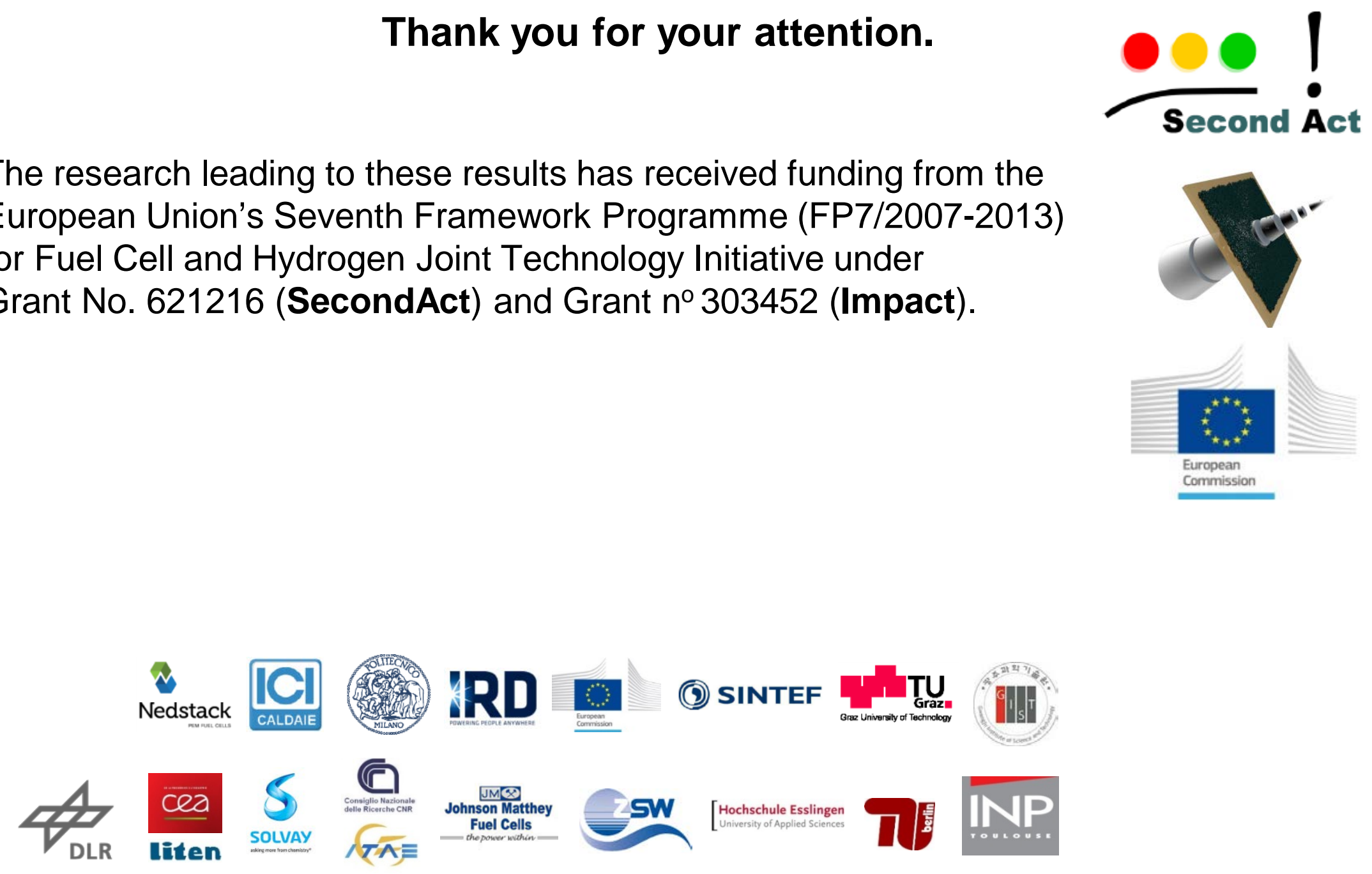